INCLUSIVE EMPLOYMENT OF DEAF PEOPLE:

STRATEGIES, CHALLENGES \& ADVANTAGES. A PRACTICAL EXAMPLE.

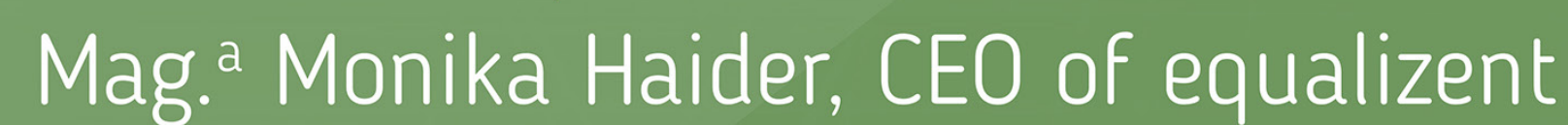

\title{
(Q) equalizent
}

\section{WHO WE ARE}

equalizent is a company with long standing expertise in Deafness, Sign Language and Diversity Management. We are a qualification centre for people who are Deaf or Hard of Hearing. Our training institute is fully accessible. We use Austrian Sign Language (ÖGS) and spoken German in our work and 30\% of our employees are Deaf or Hard of Hearing.

\section{WHAT WE DO}

Our specialism: All courses for Deaf people are in ÖGS. Our trainers are Deaf, and act as role models and peers for our trainees. We offer education courses, job orientation and job application training to enable inclusion in the first job market. Diversity Management: Sensitisation workshops for companies on Deafness. diversity.management.Tool! for managing diversity in companies. Diversity Ball to increase awareness of social diversity and to live it openly.

\section{WHERE WE ARE GOING}

Many occupational fields are closed to Deaf people. Every year we open a new area through political lobbying and preparation for entrance examinations in ÖGS.

We innovate to facilitate education (sign language library, museums guide, teaching materials, ....). Our aim is to spread our expertise to other countries.

\section{DIVERSIFIED}

LANGUAGES

JOB APPLICATION TRAINING

EDV/MULTIMEDIA

BOOK KEEPING

EXCAVATOR LICENSE

CONFLICT MANAGEMENT

\section{INCLUSION}

INTEGRATION ASSISTANCE

WORK TRAINING

TRAINEESHIP

PREPARATION COURSES

MORE THAN 70\% WHO FINISH A

VOCATIONAL COURSE FIND

AN EMPLOYMENT

\section{NEW PATHS}

DENTAL TECHNIQUES

FAMILY ASSISTANCE

KINDERGARTEN

ASSISTANCE PEDAGOGY

2D \& 3D ANIMATION

FAMILY ASSISTANCE \&

APPRENTICESHIP

OPENING NEW

OCCUPATIONAL FIELDS

\section{4}

\section{.}

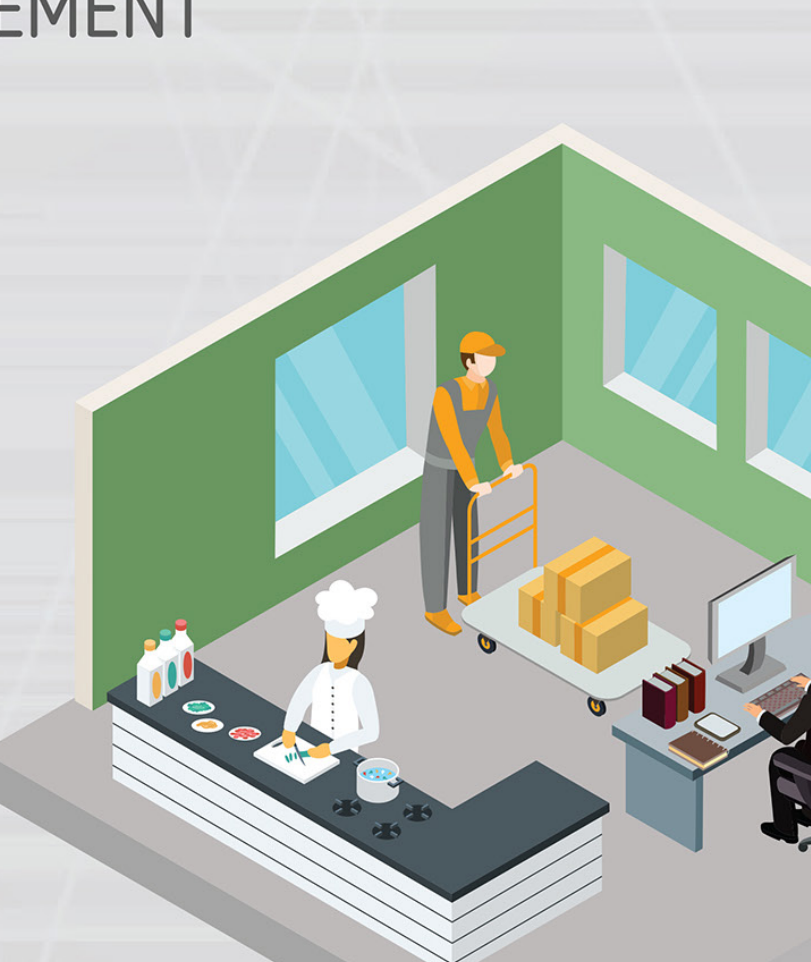

\section{COURSES}

IN AUSTRIAN SIGN LANGUAGE

\section{- FLEXIBLE}

GROUP TRAINING

INDIVIDUAL TRAINING

WEBINAR

E-LEARNING

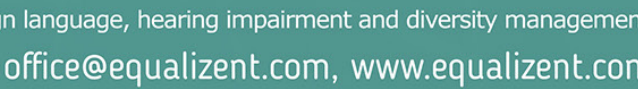

